\title{
Goat Farming and the Phenomenon of Theft in Menoua Division in the Western Region of Cameroon
}

\author{
Guillaume Hensel Fongang Fouepe ${ }^{1, *}$, Hubert Noel Takam Tchuente ${ }^{1}$, Alain Hervé Wouapi Napi ${ }^{1} \&$ Félix \\ Meutchieye ${ }^{2}$ \\ ${ }^{1}$ Department of Rural Socio-Economics and Agricultural Extension, Faculty of Agronomy and Agricultural Sciences, \\ University of Dschang, Cameroon \\ ${ }^{2}$ Department of Animal Science, Faculty of Agronomy and Agricultural Sciences, University of Dschang, Cameroon \\ *Correspondence: Department of Rural Socio-Economics and Agricultural Extension, Faculty of Agronomy and \\ Agricultural Sciences, University of Dschang, Cameroon. Tel: 237-696-206-204. E-mail: \\ guillaumefongang@yahoo.fr
}

Received: November 8, 2019 Accepted: January 3, 2020 Online Published: April 2, 2020

doi:10.5430/wjss.v7n2p17 URL: https://doi.org/10.5430/wjss.v7n2p17

\begin{abstract}
This study focuses on the theft of animals, particularly the case of goats in Menoua division in the Western Region of Cameroon. The aim is to analyze the phenomenon of goat theft and to bring out the consequences, including the answers developed and proposed by farmers. A sample of 140 goat breeders and 20 former goat keepers were surveyed and interviews were conducted with 18 authorities and resources person. The primary data obtained is analyzed using descriptive statistical methods with SPSS. Those obtained through the interview guides were analyzed through thematic analysis. It emerges that goats are stolen both during the day and at night. Discreet theft, by car or motorbike, and direct physical assault of the breeder are the main techniques/methods used by thieves. This theft phenomenon leaves consequences, in the social, economic and technical domains, which discourages enthusiasm of breeders and investments in this sector. In reponse, 50\% of the breeders' surveyed keep their goats in the family home which they regularly monitor. $25.6 \%$ have taken no action and $12.6 \%$ use watchdogs or built pens. These main methods developed against theft remain ineffective. However, vigilance committees used by $3.8 \%$ appear to be more productive and contribute to lowering this theft phenomenon whereas security services instead place emphasis on patrols they deem efficient.
\end{abstract}

Keywords: goat theft, goat keepers, perception, farmers' answers, Menoua, Cameroon

\section{Introduction}

Population growth in developing countries is galloping and represents a great challenge for food security (Brunel, 1999; Fongang, 2009; Griffon, 2006). Cameroon plans to reduce the monetary poverty rate from $39.9 \%$ in 2007 to $28.7 \%$ by 2020 . This will lead to significant improvements at the level of its food security. For this purpose, the Cameroon government established a Growth and Employment Strategy Paper (GESP). The Cameroonian government's strategy to meet the nutritional needs of the population with regard to animal production is to promote the improvement of short-cycle livestock (Document de Stratégie pour la Croissance et l'Emploi [DSCE], 2009).

At the global level, the development of livestock sector represents a major issue because it provides over half of the value of global agricultural output and one third in developing countries; at the same time, it significantly contributes to the livelihoods of rural population in developing countries (Cornelis et al., 2001). Livestock contributes up to $40 \%$ of the global value of agricultural production and maintains the livelihoods and food security of almost one billion people (Herrero, Havlik, McIntire, Palazzo \& Valin, 2014). In Cameroon, livestock breeding is currently emerging as a growth sector for the Cameroonian economy. It contributes about 165 billion CFA francs of the Gross Domestic Product (GDP) and provides income to nearly $30 \%$ of the rural population (Hamadou, 2001). In the strategic paper of the livestock, fisheries and animal industries sub-sector, small ruminants occupy a prominent place among short cycle livestock breeding promoted by the Cameroonian government (Ministère de l'Elevage, des Pêches et des 
Industries Animales [MINEPIA], 2011). Goats, more rustic than sheep, are found throughout the national territory; and this better explains the importance of their breeding. The goat population is the second highest in Cameroon after poultry in terms of head count (MINEPIA, 2013). The size of the national herd is estimated at 6.298.059 heads for an estimated production of 22.500 tons which would reach 30.000 tons by 2020 . However, it remains below the potentials of this sub-sector due to multiple constraints (Bouba, 2006).

Among the threats to agricultural and breeding systems in this case, one can list: rise in temperatures, long duration of drought periods, rainfall variability, increased frequency of floods, proliferation of parasites, the emergence and re-emergence of diseases, social changes (price volatility, population growth, rising prices of input and conflicts) (Yapi-Gnaore, Vall, Havard, Kanwe, \& Sangare, 2014). Theft is one of the threats which have not been sufficiently taken into account at the level of livestock policies, yet its socioeconomic impact is considerable. This observation is all the more relevant that in Cameroon, theft has not yet been mentioned in the strategy of the livestock sub-sector. In reality, cattle theft is described as the most serious rural crime (Barclay, 2001; Ministère de l'Elevage et des Productions Animales [MEPA], 2013; WASDA, 2007). It is one of the sources of livestock loss and even the main constraint to livestock development in small ruminants (Djomika, 2013; Mahamat, 2013; Nkonki-Mandleni, Ogunkoya, \& Omotayo, 2019; Ogada et al., 2003; Tchouamo, Tchoumboué, \& Thibault, 2005; Tendonkeng et al., 2013; Wikondi, 2011). Livestock theft is therefore one of the most important problems to study in order to propose solutions and to remedy. This problem remains one of the most serious problems, it could also be so violent as to cause the death of livestock owners (Clack, 2018; Gueye, 2013; Maluleke, Obioha, \& Mofokeng, 2014; MEPA, 2013; Manu, Andu, Tarla, \& Agharih, 2014).

The purpose of this study is to analyse the phenomenon of goat theft, to bring out their consequences, and evaluate the effectiveness of peasant responses in Menoua Division.

\section{Materials and Methods}

This study was conducted in Menoua Division, located in the Western Region of Cameroon. Four amongst eight subdivisions in Menoua have been chosen namely Dschang, Santchou, Penka-Michel, and Nkong-Ni because these are areas where goat farming is most widely practiced. The population of this study is made up of current and former goat breeders as well as authorities in charge of people and property security. The choice of respondents was made following the competent non-probability sampling techniques. Wilhem's network method (Snowball) of Wilhelm (2014) was used to select goat farmers and former breeders.

Resource persons were selected in the various areas where the breeders were surveyed. 140 goat breeders and 20 former breeders were surveyed and interviews were conducted with 18 resources persons (traditional, administrative, legal authorities; managers of zoo-technical centres and security services). The primary data was obtained using a structured questionnaire addressed to the farmers and an interview guide for resource persons. Data collected focused on the socio-economic characteristics of goat farmers, their perception about theft, methods of goat theft, the consequences and responses to theft and suggestions. After data collection, Excel and Statistical Package for the Social Sciences (SPSS) was used for data entry and analysed from the questionnaires. Data from interviews were subject to a thematic analysis.

\section{Results and Discussion}

\subsection{Identification of Breeders}

Goat farming is predominantly a male activity ( $80 \%$ ) but also it is an activity carried out by the elderly. Amongst the goat breeders, $42 \%$ are over 60 years old. Besides they are mostly married $(84.4 \%)$ with a household size between 06 and 10 people for $41.2 \%$ of the sample, and between 3 to 5 people for $31.3 \%$. As far as ethnicity is concerned, the Bamiléké group is the most represented $(83.1 \%)$. Most breeders are Christians $(63.2 \%)$, but there is also a remarkable percentage of animists $(36.3 \%)$. This considerable rate of animism may be attributed to the attachment of the Bamiléké people to their ancestral customs referring amongst others to the use of goats for traditional ceremonies (dowry and other rites)

Most of the breeders surveyed are educated ( $82 \%$ ). However, $56 \%$ of them have a primary level against only $13 \%$ who have reached university level. They have a high experience in breeding, estimated at more than 10 years for the majority.

Goat breeding is considered to be a secondary activity. In fact, $51.3 \%$ of goat breeders practice farming as their main 
activity compared to only $8.1 \%$ who regard livestock as their main activity. Thus, it occupies a secondary position in the activities of a majority of goat breeders $(70 \%)$. Nevertheless, a majority $(67.5 \%)$ of goat breeders produce for sale in the market: On the contrary, breeders whose major objective is to save their earnings, for consumption or social uses (pleasure and sacrifice) represent $12.5 \%, 9.4 \%$ and $10.6 \%$ respectively.

\subsection{Peasants Perceptions on Theft}

More than half of the surveyed farmers consider goat theft a crime (67.5\%). 21\% simply take it as an act prohibited by the society and the law. Although the breeders' perception about goat theft varies depending on facts, this point of view is not shared by the administrative, legal authorities and the managers of security services. The authorities who are responsible for ensuring the security of the population and their property all agree on the fact there is no provision of the specifically addressing the perception of goat theft because the law punishes the act and not what is stolen. According to the public prosecutor of Dschang, the law speaks of theft without specifying the different types. When there is robbery, be it that of cattle, cash or any other property, the definition given by legislation is the same: embezzlement of anothers property. Theft is therefore perceived as a deprivation to the detriment of an owner.

There is a divergence of opinions amongst goat breeders on the provenance of the thieves. $38.2 \%$ of the surveyed population think the thieves are residents of the village while $38.2 \%$ believe they are strangers. Likewise, the inhabitants of the nearby villages are also suspected by $12.5 \%$ of the breeders surveyed. $11.5 \%$ of the breeders surveyed have no idea about the origin of goat thieves. However, more than $50 \%$ of traditional authorities and security officials believe that the thieves are inhabitants of the village. Even though the other resource persons do not share this opinion, they nevertheless affirm that thieves who are coming from outside do not operate without the complicity of residents of the village. In this sense, the traditional leader of a group of villages surveyed say: "these are people from outside, with the complicity of those in the village". For breeders, these accusations made against the inhabitants of the village are explained by the presence of idle unemployed or lazy youths in the village.

Those who suspect strangers rely on the lack of reliable information to blame some suspicious people within the village. These thieves would be mostly young. Indeed, $38.8 \%$ of breeders surveyed strongly think that they are between 20 to 29 years old. However, a third of this population says they have no clear idea concerning the age of these thieves.

Breeders have different perceptions about the motivations that drive these thieves to perpetrate their crimes. The main reason given by the breeders is unemployment (31.3\%). $75 \%$ of the managers of security services share this opinion. Managers of security services think the main motivation of theft is poverty. Still, many other secondary reasons were listed: laziness, the desire to steal maliciously, low education level associated with joblessness. For the surveyed previous breeders, $16.9 \%$ ignore the motives behind theft. On the other hand, even if breeders did not mention it, for the authorities, the fact that goats are often abandoned in the bush or at the roadside (photo 1), at the mercy of thieves. It is thus, a failure in the protection of farming systems which favours theft.

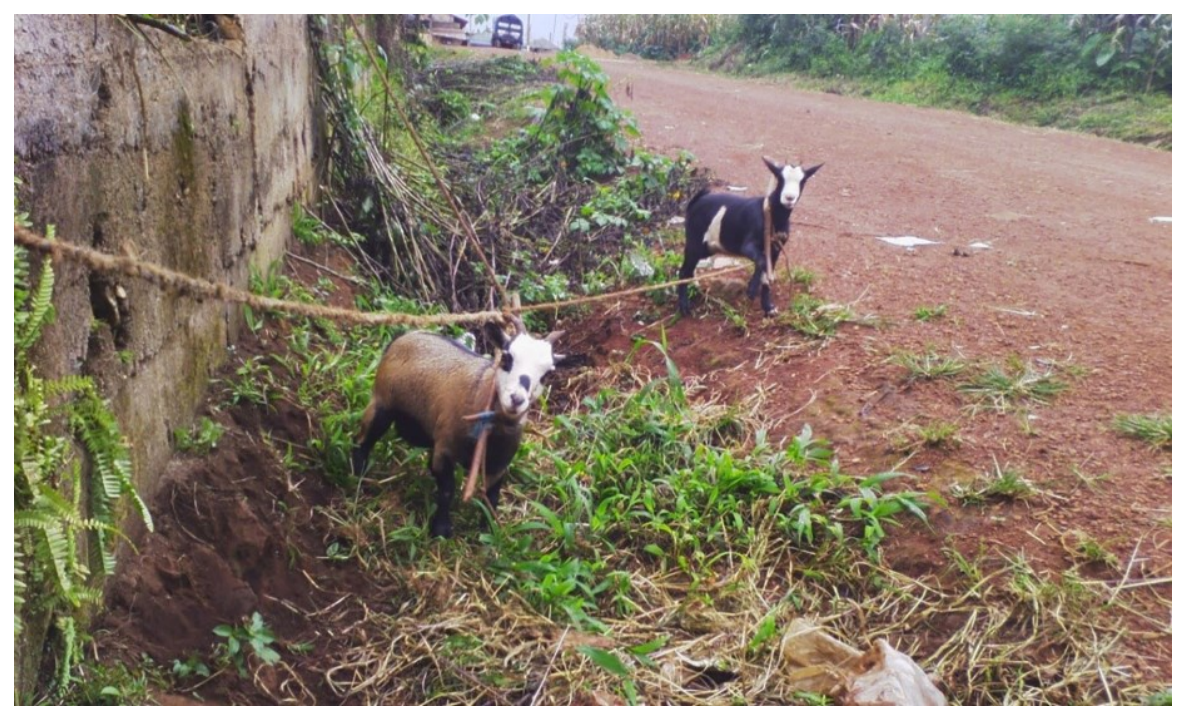

Photo 1. Goats Thethered by the Roadside 


\subsection{Methods of Goat Theft}

Goats are stolen throughout the year. However, according to the surveyed breeders, the frequency of theft is higher during specific periods. Though just over one quarter (26.3\%) agree to the view that there is no specific period for theft, others who seem to have been more attentive about the phenomenon think it is more frequent at some specific periods. Following this, $25.6 \%$ think that goat theft mainly occurs during the festive period of funerals, annual family meetings and holidays. $16.9 \%$ of the surveyed breeders point out the phenomenon equally accentuates when students go back to school. Even if 3.8\% believe that theft generally happens on the eve of the local weekly market day or on the weekly market days, more than $25 \%$ of the authorities declare that they receive complaints during these days. According to them, the market day is a favourable time for stealing because on that day, all the farmers go to the market and leave their goats without any surveillance. Also, when thieves perpetrate their crimes on the eve of a nearby villages' weekly market day, they easily get rid of the stolen goats by selling them on the market day.

Theft occurs at all periods during the day but it is more frequent in the afternoon periods, as shown in Figure 1.

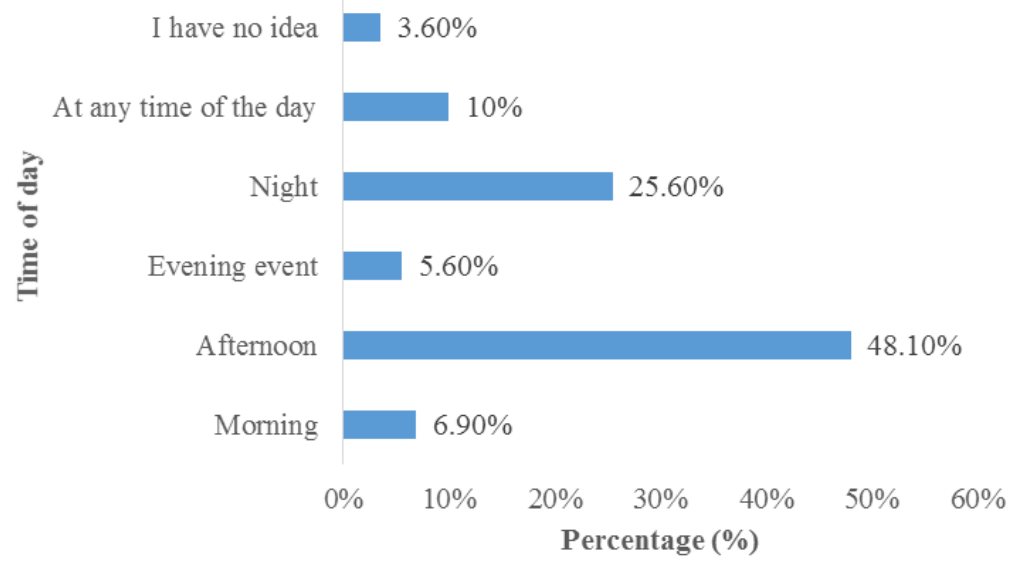

Figure 1. Distribution of Farmers Perception of Time of Day during Which Theft Takes Place

Figure 1 shows that $48.1 \%$ of the surveyed breeders think that theft always occurs in the afternoon. It is favoured by the absence of the inhabitants of the village during that particular period because they are working in their farms or doing other activities out of their family homes where goats are kept.

Theft techniques used are numerous and diverse, as shown in Table 1.

Table 1. Distribution of Breeders According to Goat Theft Techniques

\begin{tabular}{lc}
\hline Theft techniques & Relative frequencies \\
\hline Discreet theft & 78.1 \\
Car or motorcycle theft & 11.3 \\
Theft with aggression against the breeder & 5.0 \\
I have no idea. & 3.7 \\
Armed robbery & 1.3 \\
Destruction of the animal pen & 0.6 \\
\hline
\end{tabular}

Table 1 shows that only two of the identified theft techniques are frequently being used by goat thieves. They are either discreet or done with a car or motorbike. Talking of discreet stealing, it is the most expanded technique both day and night. Thieves who make use of this technique proceed in various ways; the main purpose not to be seen while stealing.

For some people, thieves spy on goat owners untill they are sure that nobody is at home. Then they unleash the goats (during the day) or they break-up the pens and take the goats when everybody is asleep. Sometimes they use some strategies to avoid the goats from bleating and alarming the owners. For others, they stay at the roadside in the quarters. When they observe a goat, they make sure nobody is around then they cut off its rope and go into the 
bushes to kill the goats. They eventually return with the slautered animal in a bag. Talking about theft using a car or a motorbike, thieves almost proceed in the same way like the previous technique. Some have "informants" who go across the quarters and target goats that have been left alone by the streets. When there is a favourable time, they come with a car (with tinted windows), cut the rope, and take away the goat. Other thieves station their cars and behave as if they want to urinate, then they watch for a while and when it is a good time (when no one is watching them) they cut away the goats' rope and carry them into the vehicle. This technique is also practiced both by night and day but mostly during the day.

\subsection{Consequences of Goat Theft}

\subsubsection{Technical Consequences}

The current herd of goats under the influence of theft is constantly decreasing. This remark was made by certain managers of zoo-technical centres and administrative authorities during interviews. And the farmers identified this when data was being collected. The number of animals has reduced for $61.9 \%$ of the surveyed breeders because of theft while only $11.3 \%$ have increased their herds despite the occerence of theft. Moreover, while visiting the herdsmen, it has been realized that they largely tether their goats at their homes or near the family compound because of theft. Choosing where to tether the goats is no more based on the availability of fodder but now it is a question of the distance which can guarantee a certain margin of security.

In fact, breeders are not keeping their goats away from home; they are kept in areas which enable a clear visibility in order to make permanent checks. The immediate consequence of this practice is the unbalanced diet of the animals, most of the time they cannot cover their nutritional needs for an optimal growth. Indeed, the fodder's quality induced by the practice of pickets (photo 2) and loins (photo 1) in marginal areas expose the goats to malnutrition problems.

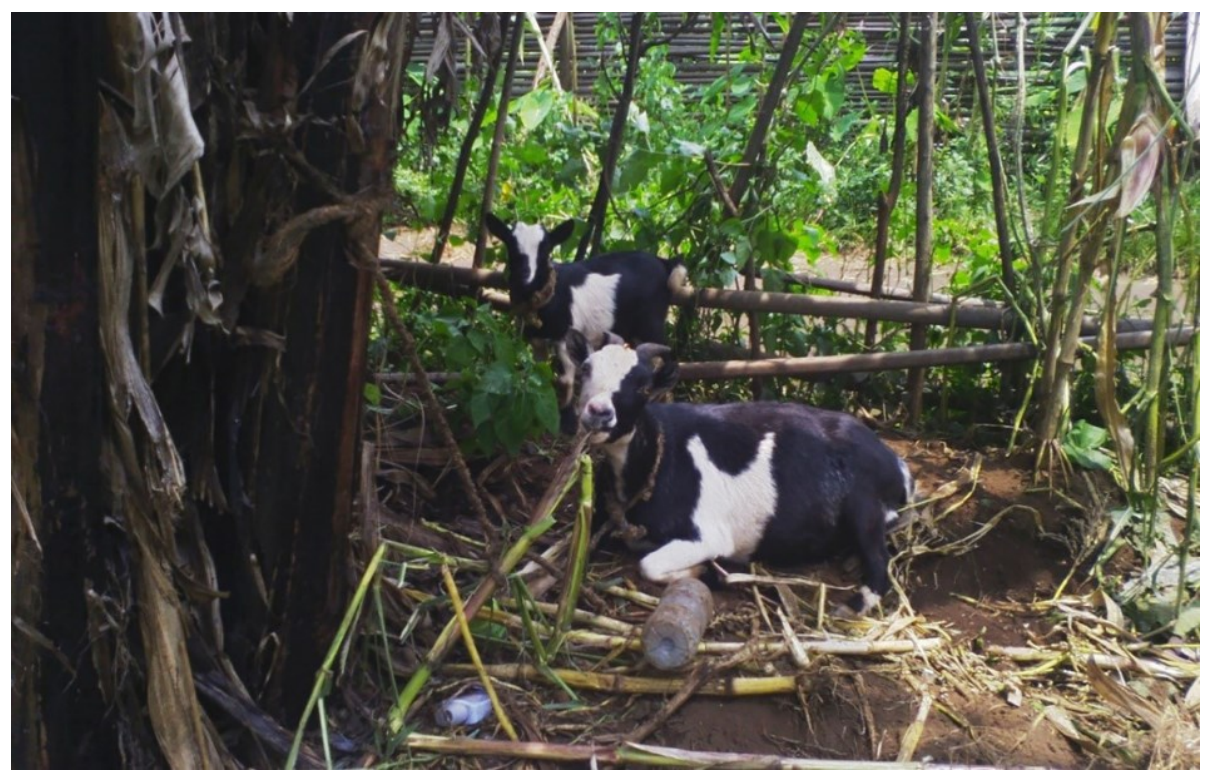

Photo 2. Goats in a Pen within the Family Compound

\subsubsection{Social Consequences}

Goat theft has engendered many social consequences. In rural areas, goats represent a kind of savings made by the breeders in order to cater for various needs such as health and childrens' education. Goat theft thereby reduces their capacity to meet those needs. Concerning the impact of goats' theft on education, there are two divergent views: $53.1 \%$ of the breeders surveyed hold the view that theft affects the purchase of textbooks and paying of school tuition whereas $40.7 \%$ think that theft does not affect their childrens education. For the effects of theft on household health, a proportion of $53.1 \%$ believe that it limits the access to medication while $38.6 \%$ think it has no influence on the household's health.

In addition, theft affects the security of the breeders. $83.8 \%$ have declared they feel insecured. Further, although $33.1 \%$ of the breeders certify that they have never witnessed a life-threatening theft case; another larger proportion say the opposite. $63.1 \%$ declared either being victims of assaults or have got information about cases which involved 
life-threatening theft.

Also, since less than $10 \%$ of the surveyed breeders possessed some information about the identity of the thieves, goat theft brings suspicion, distrust and conflicts in the breeder communities which disturbs the social environment. For $36.3 \%$ of the respondents, theft creates a sentiment of suspicion within the community. For a proportion of $28.8 \%$ it is all about distrust whereas others $(8.1 \%)$ say that it generates conflicts. In the same vein, most of the administrative authorities surveyed think that theft creates a feeling of fear and suspicion that disturbs the social atmosphere.

It is within the disturbance of the social climate that some managers of security services often receive defamative complaints with names, usually people who are falsely accused. Theft is the root cause of the abandonment of goat farming. In fact, $90 \%$ of the authorities think that theft is a source of discouragement, which drives the breeders to completly abandon the activity. Also $75 \%$ of the former breeders actually abandoned their activities because of theft against $25 \%$ who gave up due to illness only. Amongst the former breeders who gave up because of theft, a proportion of $46 \%$ did it due to theft only, the others did it because of theft, illness (27\%) and lack of pasture.

\subsubsection{Economic Consequences}

Goat theft causes significant economic losses, as shown in Table 2.

Table 2. Descriptive Statistics on Stolen Goats and Their Cost in FCFA

\begin{tabular}{lrrrrr}
\hline Variable & Minimum & Maximum & Sum & Mean & Standard deviation \\
\hline Stealing frequency per year & 1 & 10 & 185 & 1.16 & 1.515 \\
Number of stolen goats per year & 1 & 12 & 319 & 2.03 & 2.829 \\
Estimated cost of stolen goats per year & 10000 & 600000 & 7377400 & 49021.79 & 83983.727 \\
\hline
\end{tabular}

Table 2 shows that goat keepers are victims on average of one case of theft every year with a value of 49021,79 CFA francs for two goats stolen. In sum, from a sample of 160 breeders, every year, 185 theft cases are recorded with 319 goats stolen for a value of 7.4 million CFA francs. This important economic loss due to theft was also revealed by Manu et al., (2014) in the North-West Region of Cameroon. According to the authors, theft of oxen between 2008 and 2012 has caused an estimated loss of about 1.3 billion CFA francs. In other words, a loss of 260.000 CFA francs every year was recorded because of theft of oxen in the North-West of Cameroon. Likewise, Lombard, Niekerk \& Maré (2017) noted that in the Eastern Cape province of South Africa, the direct annual losses linked to theft of livestock amount to around 7963284605 CFA francs. This phenomenon would be even more accentuated in South Africa. Clark (2018) reports that there has been a gradual increase in the number of livestock units stolen, irrespective of the type of animal, since 2013, reaching unacceptably high figures. According to Clark (2018), 115 goats are stolen every day in South Africa in 2017.

\subsection{Responses to the Phenomenon of Goat Theft}

\subsubsection{Measures Taken by Breeders to Prevent Theft}

Most of the breeders work individually to deal with the phenomenon of theft which disturbs goat production, as shown in Table 3.

Table 3. Distribution of Farmers according to Measures Taken to Prevent Theft

\begin{tabular}{lr}
\hline Preventive measures against theft & Frequency \\
\hline I put the bells around their necks & 0.6 \\
I make the goats sleep in the house and sometimes in my room & 0.6 \\
I pray to God & 1.9 \\
I rein the goats in the field where I work & 1.9 \\
I limit the grazing time in the morning and keep them in the afternoon & 3.1 \\
I work in the villages' vigilance committee & 3.8 \\
I built a pen and keep them inside & 6.3 \\
I put a watchdog & 6.3 \\
I'm not doing anything. & 25.6 \\
I tether goats to the house or surroundings and regularly monitor them & 50.0 \\
\hline
\end{tabular}


Table 3 shows that the majority of the breeders (50\%) keep their goats at home or in the vicinity and regularly monitor them. Yet a proportion of $25 \%$ take no preventive measure. Similarly, a few breeders $(1.9 \%)$ believe that God is the only one who can spare them from theft. Nonetheless some breeders $(6.3 \%)$, though they represent a minority, build pens for better security of their animals while still, others prefer to have watchdogs $(6.3 \%)$. The results are similar to those found by Manu et al (2014) in North-Western Cameroon. In the light of these results, the main means of fighting against theft of oxen in that region were: to build night pens, to check herds and shepherds, to increase the number of watchmen and to use watchdogs. As far as occultism is concerned (resort of traditional healers, use of fetishes, sacrifices...), only 4 people out of the 160 respondents practice this method to prevent theft.

3.5.2 Actions Taken by the Authorities to Fight against Goat Theft

Table 4 shows the distribution of actions by the authorities to combat theft.

Table 4. Distribution of Actions by the Authorities to Combat Theft

\begin{tabular}{|c|c|c|}
\hline Authorities & Anti-theft actions & $\begin{array}{l}\text { Fréquences } \\
\text { relatives }\end{array}$ \\
\hline Security services & Day and night patrols & 100 \\
\hline \multirow{2}{*}{$\begin{array}{l}\text { Zootechnical } \\
\text { centres }\end{array}$} & We can't do anything at our level & 75 \\
\hline & $\begin{array}{l}\text { We check the hide of goats that are killed for emblems to determine if they } \\
\text { have been reported stolen. }\end{array}$ & 25 \\
\hline \multirow{2}{*}{$\begin{array}{l}\text { Zootechnical } \\
\text { centres }\end{array}$} & Transfer of thieves to the gendarmerie & 40 \\
\hline & Establishment of self-defence committees & 60 \\
\hline \multirow[t]{2}{*}{$\begin{array}{l}\text { Sub-divisional } \\
\text { officers }\end{array}$} & $\begin{array}{l}\text { Raising awareness among herders so that they no longer tether goats by the } \\
\text { roadside }\end{array}$ & 50 \\
\hline & Establishment of self-defence committees & 50 \\
\hline Attorney & Enforcement of the law & 100 \\
\hline
\end{tabular}

As shown in Table 4, many authorities take action in the fight against goat theft in Menoua Division. It emerges from table 4 that, the managers of security services in the performance of their official duties patrol both day and night. They crisscross the villages with the aim of discouraging any people with bad intentions and identify new residents. The Sub-divisional officers, for their part, combine efforts for the establishment of vigilance committees in their jurisdiction in reaction to the phenomenon of goat theft. Also, another action taken is to sensitize the breeders for them to stop tethering their goats on the roadside (photo2). Traditional authorities are not left behind because they also organize vigilance committees in their respective villages; some of them act harshly and prefer sending the thieves to the police station. For them, the best means to reduce theft is to severely punish the arrested perpetrators. They think that no amicable settlement is possible when a theft is caught red-handed, he or she must be sent to the police station and taken to the prosecutor so that it will serve as a lesson for him/her and other thieves.

Finally, the prosecutor, representing the judicial services simply applies the current law on theft in accordance with article 318 of the Penal Code. The application is not always automatic because the public authorities are willing to relieve the prisons. Therefore, some theft cases are judged with an accordance of "leniency" for first-time offenders in order to avoid overloaded prisons which are already full.

\subsection{Effectiveness of the Solutions}

3.6.1 Effectiveness of the Measures Taken by the Breeders

Figure 2 shows the effectiveness of the measures taken by breeders. 


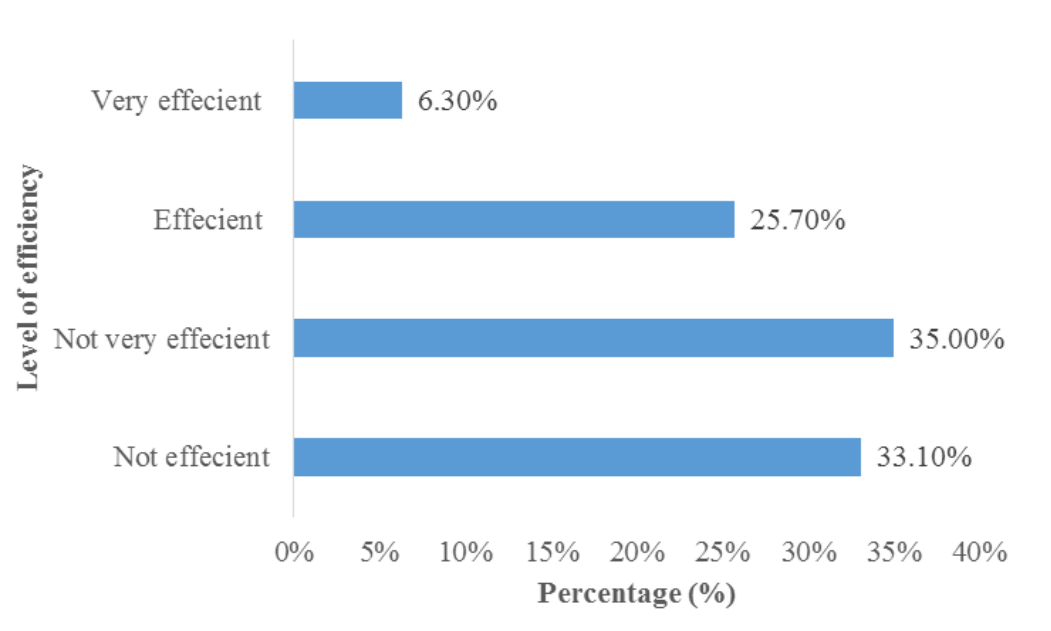

Figure 2. Distribution of Farmers According to the Level of Efficiency of all Measures Taken

Figure (2) shows that $33.1 \%$ of all the measures taken by the breeders to deal with the problem of theft are not effective at all. Though a large number of the respondents think that they are efficient, only a proportion of $6.3 \%$ believe in their effectiveness against 35\%. 25.7\% think they are fairly. This high proportion (68.1\%) of non-efficient and/or of low efficiency in adopted measure is a simple consequence of the phenomenon of theft which persists in spite of the precautions taken by the breeders. This can also be attributed to the precarious nature of the measures taken by the breeders in terms of protecting and securing their livestock.

An analysis of the level of effectiveness of each of the solutions, individually show that the most practiced solution is mainly inefficient. As shown in Table 5.

Table 5. Distribution of Breeders according to the Level of Efficiency of Each Disposition Taken (Percentage)

\begin{tabular}{|c|c|c|c|c|}
\hline Measures taken by farmers to prevent theft & $\begin{array}{c}\text { Not } \\
\text { effecient }\end{array}$ & $\begin{array}{l}\text { Not very } \\
\text { effecient }\end{array}$ & Effecient & $\begin{array}{c}\text { Very } \\
\text { effecient }\end{array}$ \\
\hline I work in the village vigilance committee & 0 & 16.5 & 16.5 & 67 \\
\hline I tether goats to the house or surroundings and regularly monitor them & 16.25 & 48.75 & 32.5 & 2.5 \\
\hline I'm not doing anything. & 80.49 & 12.19 & 7.32 & 0 \\
\hline I built a pen and keep them inside. & 0 & 60 & 30 & 10 \\
\hline I pray to God & 33.33 & 0 & 66.66 & 0 \\
\hline I put the watchdog on & 30 & 10 & 50 & 10 \\
\hline I make the goats sleep in the house and sometimes in my room & 0 & 0 & 100 & 0 \\
\hline I put bells on the goat's necks & 0 & 0 & 100 & 0 \\
\hline I limit the grazing time in the morning and keep them in the afternoon & 0 & 60 & 20 & 20 \\
\hline I tether goats to the field I work & 33.33 & 33.33 & 33.33 & 0 \\
\hline
\end{tabular}

Table 5 shows that half of the respondents keep their goats at home but just a few of them (2.5\%) found this very efficient against $16.25 \%$ who declared that this action was inefficient. However, $16.75 \%$ of those who chose this practice judge it to be a little bit efficient and $32.5 \%$ judge it efficient. All the same, a quarter of breeders who take no action against this phenomenon nevertheless acknowledge its impact since $80.49 \%$ of them judge their inaction as counterproductive and inefficient. Yet the vigilance committee of the village (which seems to be one of the less used responses) appears to have the most satisfying level of effectiveness according to $67 \%$ of the people who practice this method. Thus, vigilance committee and watchdogs are the most efficient solutions against goat theft.

\subsubsection{Level of Effectiveness}

During the different interviews with the authorities, it is generally accepted that their actions to deal with the phenomenon of theft are effective. However, one Sub-Divisional officer amonsgt three noted the fact that vigilance 
committees have difficulties doing their work and only show up after an occurrence of theft. That said, he believes that they are very effective anytime they are given the opportunity to intervene. Traditional authorities share the same opinion as they reveal that vigilance committees are effective but could be very efficient if the members were receiving substantial compensation. For the managers of security services, patrols carried out day and night are effective. They mention the fact that patrols dissuade and change negative intentions but they could be more effective with the cooperation of the population. However, if only $10.7 \%$ of farmers have ever had to report cases of theft to the village Chief or security services; $89.3 \%$ on the other hand have never done so for several reasons. Possible reasons explaining why so many cases go unreported are that they have not yet been victims of theft, lack of information on the identity of thieves, and lack of evidence and fear of retaliations. Moreover, the Prosecutor of the Republic, with regards to the level of effectiveness of the action of the judicial services, considers that it is difficult to speak out on that because the number of cases that arrive at the level of the courts remain low.

\section{Conclusion and Recommendations}

\subsection{Conclusion}

Goat farming is mainly practiced by the elderly and married men. Their low level of education is compensated by their longstanding experience in breeding. Goats are stolen by day and night throughout the year. Techniques employed by the thieves are diverse and discreet. Theft has many consequences at the social (it affects the purchase of textbooks, access to medication, disturbs the social climate, generates feeling of insecurity and favours the abandonment of the activity), economic (causing loss of income) and technical levels (reduction of the herd, affecting animals' nutrition). In reponses to this, the majority of the surveyed breeders keep their animals at home and constantly monitor them; but this remains somewhat inefficient. However, even if theft cases continue to happen, the village vigilance committees proved to be very effective and contribute in the reduction of the phenomenon of theft when they function properly. Patrols are the main actions during the day and night by the security services that seem to work efficiently indeed. Yet, it does not always succeed to discourage or stop the thieves. In order to resolve the problem of theft, authorities suggest an open collaboration from the populations, and the latter's claim that farmers would appreciate receive subventions to build pens (although many of them did not talk).

\subsection{Recommendations}

The following are recommendations to effectively fight against goat theft and solve this problem in Menoua Division in the West Region of Cameroon.

- Breeders ought to cooperate with the traditional authorities and security services by denouncing the thieves and their accomplices.

- Support the vigilance committees and help them in their organisation in order for them to function both during the day and night which in turn, reinforces the action of security services.

- Structure cattle markets to enable traceability of each animal sold

- Avoid tethering their animals on the roadside.

- Finally, it would be desirable to increase interest on secured agricultural systems with a focus on secured livestock production.

\section{References}

Barclay, E. (2001). A Review of the Literature on Agricultural Crime. Report to the Criminology Research Council. Institute for Rural Futures University of New England Armidale, p67.

Bouba, M., (2006). Evolution et situation actuelle de l'élevage au Cameroun. Rapport de synthèse du MINEPIA, Cameroun, p42.

Brunel, S. (1999). La faim dans le monde. Comprendre pour agir. Presses Universitaires de France: Paris.

Clark, W. (2018). Livestock Theft a Global and South African Perspective. National Red Meat Producers Congress 11 and 12 September 2018, Royal Elephant Hotel and Conference Centre Pretoria. Petroria, South Africa.

Cornelis, H., Van Veen, T. S., Brandenburg, B., Gauthier, J., Le Gall, F., Mearns, R., \& Simeon, M. (2001). Livestock development: implications for rural porvety, the environment and global food security, Directions in development. The Word Bank: Washington, D.C. p96. 
DSCE (Document de Stratégie pour la Croissance et l'Emploi). (2009). Cadre de référence de l'action gouvernementale pour la période 2010-2020. Cameroun, p174.

Fongang, G. (2009). L'agriculture durable: quels défis aujourd'hui? Ecovox, ISSN 1026 - 2261, Le magazine de l'écologie et du développement durable. N42 Juillet - Décembre 2009. Bafoussam.

Griffon, M. (2006). Nourrir la planète, pour une révolution doublement verte. Odile Jacob: Paris p456. https://doi.org/10.3917/afco.219.0203

Gueye, A. B. (2013). Organized crime in the Gambia, Guinea-Bissau and Senegal. In E.E.O. Alemika (Ed.), the impact of organized crime on governance in West Africa. Abuja: Friedrich-Ebert-Stiftung. (Abuja Regional Office, Nigeria), p101.

Hamadou S. (2001). Un nouveau cadre de l'exercice des activités de santé animale au Cameroun. Afrique Agriculture, 294, 30-31.

Herrero, M., Havlik, P., McIntire, J., Palazzo, A., \& Valin, H. (2014). L'avenir de l'élevage africain : Réaliser le potentiel de l'élevage pour la sécurité alimentaire, la réduction de la pauvreté et la protection de l'environnement en Afrique sub-saharienne. Bureau du représentant spécial des Nations Unies pour la sécurité alimentaire et nutritionnelle et du Coordonnateur du système des Nations Unies contre la grippe (UNSIC), Genève, Suisse, p118.

Lombard, W. A., Niekerk, H. N. V., \& Maré, F. A. (2017). Assessing the economic impact of livestock theft in the Eastern Cape province of South Africa. 21st International Farm Management Congress, John McIntyre Conference Centre, Edinburgh, Scotland, United Kingdom.

Mahamat, B. (2013). Caractéristiques socioéconomiques et techniques de l'élevage des petits ruminants dans le département de la Momo (Nord-Ouest Cameroun). Mémoire de fin d'étude d'Ingénieur Agronome. Université de Dschang: Dschang, Cameroun.

Maluleke, W., Obioha, E. E., \& Mofokeng, J. T. (2014). Assessment of Policing and Prevention Strategies of Stock Theft in South Africa: A Case Study of Giyani Policing Area, Republic of South Africa. Mediterranean Journal of Social Sciences, 5(23), 2148-2157. https://doi.org/10.5901/mjss.2014.v5n23p2148

Manu, I. N., Andu, W. N., Tarla, D. N., \& Agharih, W. N. (2014). Socio-economic effect of cattle theft on the pastoralists of the North West Region of Cameroon. Scholarly Journal of Agricultural Science, 4(6), 299-305.

MINEPIA (Ministère de l'Elevage, des Pêches et des Industries Animales). (2011). Document de stratégie du sous-secteur de l'élevage, des pêches et des industries animales, p121.

MINEPIA (Ministère de l'Elevage, des Pêches et des Industries Animales). 2013. Productions animales au Cameroun. Retrieved from http://www.minepia.gov.cm

Ministère de l'Elevage et des Productions Animales (MEPA). (2013). Cellule de prévention et de lutte contre le vol de bétail. http://www.elevage.gouv.sn/index.php/extensions/cellule-de-prevention-et-de-luttre-contre-le-vol-de-betail

Nkonki-Mandleni, B., Ogunkoya, F. T., \& Omotayo, A. O. (2019). Socioeconomic factors influencing livestock production among smallholder famers in the free state province of South Africa. International Journal of Entrepreneurship, 23(1), 1-17.

Ogada, M. O., Woodroffe, R., Oguge, N. O., \& Frank, L. G. (2003). Limiting Depredation by African Carnivores: the Role of Livestock Husbandry. Conservation Biology, 17, 1521-1530. https://doi.org/10.1111/j.1523-1739.2003.00061.x

Tchouamo, I. R., Tchoumboué, J., \& Thibault, L. (2005). Caractéristiques socio-économiques et techniques de l'élevage de petits ruminants dans la province de l'Ouest du Cameroun. Tropicultura, 23(4), 201-211.

Tendonkeng, F., Pamo, E. T., Boukila, B., Defang, H. F., Njiki, W. E., Miégoué, E., Fogang, B. Z., Lemoufouet, J., \& Djomika, J. T. (2013). Caractéristiques socio-économiques et techniques de l'élevage des petits ruminants dans la région du Sud Cameroun: Cas du département de la Mvila. Livestock Research for Rural Development, p15.

WASDA (Washington State Department of Agriculture). (2007). Seattle, WA, USA.

Wikondi, J. (2011). Caractéristiques socioéconomiques et techniques de l'élevage des petits ruminants dans le département du Mayo-Danay (Extrême-Nord Cameroun). Mémoire de fin d'étude d'Ingénieur Agronome. Université de Dschang: Dschang, Cameroun, p81. 
Wilhelm, M. (2014). Rapport de méthodes: Echantillonnage boule de neige, la méthode de sondage. Office fédéral de la statistique (OFS), Neuchâtel, Suisse, p54.

Yapi-Gnaore, V. C., Vall E., Havard, M., Kanwe, A. B., \& Sangare M. (2014). Production et gestion des connaissances pour renforcer la résilience des systèmes agropastoraux. Quatrième Semaine Scientifique agricole de l'Afrique de l'Ouest et du Centre et 11ème Assemblée Générale du CORAF/WECARD. 16-19 juin 2014, Niamey, Niger. 